\title{
Identification and Quantification of Total Polyphenols in Plants with Bioactive Potentially
}

\author{
Daniela Sandru ${ }^{1, a}$, Violeta Niculescu ${ }^{2, b}$, Ecaterina Lengyel ${ }^{1, c^{*}}$, Ovidiu Tita ${ }^{1, d}$ \\ 1"Lucian Blaga" University of Sibiu, Faculty of Agricultural Sciences Food Industry and \\ Environmental Protection, Romania \\ ${ }^{2}$ National R\&D Institute for Cryogenic and Isotopic Technologies - ICSI Rm. Vâlcea, Romania \\ e-mail: ${ }^{a}$ danielaraulea@yahoo.com, ${ }^{b}$ violeta.niculescu@icsi.ro, ${ }^{c^{*}}$ ecaterina.lengyel@ulbsibiu.ro, \\ dovidiu.tita@ulbsibiu.ro
}

Keywords: plants, bioactive potentially, polyphenols

\begin{abstract}
This meaning of this specific work is to identify and quantify the polyphenolic compounds that exist in plants with bioactive potentially. The study was monitorising 16 different plants: bilberry (Vaccinium myrtillus), artichoke (Cynara scolymus), chicory (Cichorium intybus), dumb (Teucrium chamaedrys), fennel (Foeniculum vulgare), thorn (Xanthium spinosum), juniper (Juniperus communis), mint (Mentha), cranberry (Vaccinium vitis-idaea), hawthorn (Crataegus monogyna), wormwood (Artemisia absinthium), willow herb (Epilobium), lemon balm (Melissa officinalis), St. John's wort (Hypericum perforatum), oregano (Origanum vulgare), centaury (Centaurium erythraea). The total polyphenolic compound was determined on spectrophotometric method, Folin-Ciocalteu. The polyphenols have a very wide range value starting on low amounts on centaury (Centaurium erythraea) $271.613 \mathrm{mg} / \mathrm{L}$ and reaching highest values of $5975.616 \mathrm{mg} / \mathrm{L}$ in wormwood (Artemisia absinthium). The results can be use in the design of digestive drinks in the food industry due to higher concentration of total polyphenols in the studied plants.
\end{abstract}

\section{INTRODUCTION}

Polyphenols are plant secondary metabolites and are generally involved in defense against aggression ultraviolet radiation or pathogens. In foods, polyphenols can give bitterness, astringency, color, flavor, odor and oxidation stability. Towards the end of the 20th century, epidemiological studies and meta-analyzes have suggested passing a long-term consumption of diets rich in polyphenols in plant offers some protection against developing cancer, cardiovascular disease, diabetes, osteoporosis and neurodegenerative diseases. The outer layers of plants contain higher levels of phenolics than those located in their inner maturity. The degree of maturity affects significantly concentrations and proportions of different polyphenols.

The Bilberry (Vaccinium myrtillus) is a local tree located in mountain forests; his steams are $50 \mathrm{~cm}$ high. The bilberry leaves composition is: $10 \%$ tannins, myristic acid and palmitic derived flavonoid, thiamine and minerals.

The anthocyanins from the bilberry fruits have an retinal action by inhibiting monophosphate6-glucose and antocianidele.

The anthocyanins have a positive impact on capillaries; they are vasodilators and fight against cancer $[1,2]$.

The Artichoke (Cynara scolymus) is a low temperatures sensitive herb, with globular large light purple flowers. The Artichoke leaves contain a bitter principle (cinaropicrin) cinaratriol, polyphenols, flavonoids, potassium, sterol and other bioactive compounds.

The Artichokes plant can be used in liver disease, atherosclerosis, hypercholesterolemia, indigestion, loss of appetite, anorexia, poisoning, bloating, cholesterol [3, 4].

The Chicory (Cichorium intybus) is a perennial, edible plant. It is used to treat renal and hepatobiliary diseases. The taste is a slightly bitter one. It is known for his antimicrobial activity and high anthelmintics $[5,6]$. 
The Dumb (Teucrium chamaedrys) is having adverse effects on health if consumed improperly prepared. This plant is rich in terpene compounds and glycosides [7,8]. The traditional medicine recommend this plant for treating rheumatic diseases, dyspepsia, chronic bronchitis, urinary tract infections, anorexia.In food industry it can be found in already prepared drinks.

The Fennel (Foeniculum vulgare) is a medicinal plant rich in essential oils, with antispasmice anti-inflammatory and calming effects [9].

The Thorn (Xanthium spinosum) is a herbaceous plant. It can be found in grassland near the main roads.In Thorn composition we can observe: phytosterols, caffeic acid, flavonoids and essential oil [10]. Thorn plant is used to treat prostatitis, kidney stones of hyperthyroidism, the bogs, prostate adenoma and cystitis.

The Juniper (Juniperus communis) is a resinous tree that grows in the mountain area. The leaves are dark green needle-shaped.This plant is rich in essential oils and in other kind of compounds such as: cadinene 1-4-terpineol, $\beta$-pinene, diterpene, mircens, iuniperină, invert sugar, camphene, $\alpha$-pinene, fats, organic acids (glyceric, glycolic acid, ascorbic him, acetic, formic, oxalic acid, malic acid), sucrose, waxes, resins, salts of potassium, calcium [11, 12]. The Juniper is usually used for treatding bladder stones, rheumatism, hepatitis epidermal bronchitis, enteritis, enterocolitis, as adjunctive in diabet therapy, eczema; it stimulates the secretion of gastrointestinal juices, anorexia, kidney edema.

The Mint (Mentha) is a plant widespread in the world.The mint leaves contains a significant quantity of volatile oils, tannins, flavonoids, polyphenolic substances. The volatile oil of the peppermint is having menthol, caracole, methane, thymol, menthofuran. It is highly recommended for treating diarrheal diseases, gastrointestinal. It has antiseptic and analgesic effects [13, 14].

The Cranberries (Vaccinium vitis-idaea) is a bushy shrub from acidic mountain grasslands area. The branches are harvest in spring and they are used to obtain macerates.

Its branches and fruits have in their composition tannins, [15] with a strong antioxidant effect, formic acid, valeric acid, salicylic acid, starch, dextrin, sucrose, mineral salts.

The active compounds identified by [16] lead to the treatment of diabetes, being also used in the treatment of gout, cystitis, rheumatism, diarrhea, cough, diseases of the urinary tract.

The Hawthorn (Crataegus monogyna) is a local shrub that grows through the forests, meadows, pastures, from the steppe to the mountains.Hawthorn leaves and flowers have in their composition between 1 and 3\% procyanidin flavonoids, amines, sterols, carboxylic acids, volatile oil that may have in its composition minerals, pectin, tannins.His fruits have in their composition vitamins tannins, anthocyanins, citric acid, oxalic acid, tartaric acid, choline, fructose, fatty oil, pectin, glucose, minerals $[17,18]$.

Hawthorn helps muscle to contract- especially myocardium muscle-by using the leaves and flowers. It is also used as a dilator of heart vessels.Hawthorn alcohol-based extracts helps to regulate the heart rate, to removed cardiac arrhythmias, to increase blood flow and the blood pressure. The Hawthorne's is well known natural remedy of sedative and diuretic effects.

The Wormwood (Artemisia absinthium) is a perennial plant with many purposes such as stimulant of gastric secretions,diarrhea, inflammatory, anthelmintic, with disinfectant properties, anthelmintics, diuretics, anti-inflammatory, depurative, laxative, acting as healing internally and externally $[19,20]$.

Willow Herb (Epilobium) plant is a widespread with pharmaceutical applications in the treatment of $\mathrm{BPH}$, a cystitis, prostate cancer and genital or even viral hepatitis type A, B or C, peptic ulcer, nephritis or urinary lithiasis [21].

The Lemon balm (Melissa officinalis) prevalent spontaneously in Romania with a lot of beneficial effects on stomach problems usad frequently on treatin the headaches, dizziness obesity or stress. The volatile oils contained are rich in compounds such as bioflavonoids, caffeic acid, ursolic acid or oleanolic acid [22, 23].

St. John's Wort (Hypericum perforatum) is a plant known in traditional and natural medicine It contains volatile oils, flavonoids, hyperin, resins, choline, organic acids (caffeic, chlorogenic 
acid), tannins, beta-carotene, hypericin, pseudohipericina, fitoncide. The plant has antiinflammatory, antiseptic, painkillers and sedatives properties [24, 25].

Oregano (Origanum vulgare) is a plant rich in essential oil, antocianide, flavonoids, thymol, carvacrol, tannins, minerals. It is having antispasmodic, antiseptic, sedative, bronchodilator benefits. It can be successfully used in the treatment of various diseases such as: diseases stomach, dysentery, bronchial asthma, bronchitis, anorexia, asthenia, colitis, insomnia, flu-stomatitis, tracheitis, pharyngitis, intestinal disorders, but also in the treatment of burns, headache, eczema, periodontitis, gingivitis, otitis [26, 27].

Centaury (Centaurium erythraea) is a plant of 10-40 $\mathrm{cm}$ height. Its composition is having bitter substances like secoiridoide, glucosides, genţiapicrină, centaurozide, genţianină and phenolic acids - p-coumarin, ferulic acid, protocatechinic acid, and minerals. The specific studies on this plant revealed an anti-inflammatory antipyretic and anti tumor necrosis action [28].

\section{MATERIALS AND METHODS}

Plants with bioactive potentially: blueberries, artichoke, chicory, dumb, fennel, thorn, juniper, mint, cranberry, hawthorn, wormwood, willow herb, lemon balm, St.John's worth, oregano, centaury. The plants was dried and ground. The powder was homogenized in ethanol $50 \%$ for extraction of bioactive components in a ratio of 1:10 for 24 hours. The samples were filtered and brought to dryness. The extract was dissolved in ultrapure water 1:1.

The quantitative evaluation of the polyphenols has been provide by the Folin Ciocalteu method modified.

The Folin-Ciocalteu method is based on the oxidation of polyphenols using a molibdowolfram at solution ( $\mathrm{Na} 2 \mathrm{WO} 4$ / Na2MoO4).

$\mathrm{O} 2$ result from this reaction. This is reactin with molybdate in order to form ion $(\mathrm{Mo} 4+)$ (blue), whose absorbance is followed spectrophotometrically in the range 420-1000.

The maximum absorbance was detected at $765 \mathrm{~nm}$.

This reaction took place in a basic medium. Like reference AO gallic acid was used.

\section{RESULT AND DISCUSSION}

After performing the measurement on 16 samples we can notice that the values of polyphenols expressed in gallic acid were between $271.613 \mathrm{mg} / \mathrm{L}$ and $5975.616 \mathrm{mg} / \mathrm{L}$ (Figure 1).

The Wormwood (Artemisia absinthium) plant has reached the maximum value-5975.616 $\mathrm{mg} / \mathrm{L}$, followed by artichoke (Cynara scolymus) with $4673.128 \mathrm{mg} / \mathrm{L}$ and juniper (Juniperus communis) with $3172.662 \mathrm{mg} / \mathrm{L}$.

The polyphenols values situated between $1000 \mathrm{mg} / \mathrm{L}$ to $3000 \mathrm{mg} / \mathrm{L}$ on mint (Mentha) with $2667.486 \mathrm{mg} / \mathrm{L}$, cranberry (Vaccinium vitis-idaea) with $2483.004 \mathrm{mg} / \mathrm{L}$, blueberry (Vaccinium myrtillus) with $1607.733 \mathrm{mg} / \mathrm{L}$ and hawthorn (Crataegus monogyna) with $1067.275 \mathrm{mg} / \mathrm{L}$.

Another group of plants is presenting an accumulation of polyphenols in amounts between $700 \mathrm{mg} / \mathrm{L}$ and $900 \mathrm{mg} / \mathrm{L}$.

We can notice that the fennel (Foeniculum vulgare) and the thorn (Xanthium spinosum) with values very close to $856.170 \mathrm{mg} / \mathrm{L}$ respectively $856.975 \mathrm{mg} / \mathrm{L}$, together with Dumb (Teucrium chamaedrys) with $871.775 \mathrm{mg} / \mathrm{L}$.

Willow herb (Epilobium) and chicory (Cichorium intybus) average values are $8 \%-10 \%$ lower than the thorn and fennel, values that reached $773.100 \mathrm{mg} / \mathrm{L}$, respectively $795.360 \mathrm{mg} / \mathrm{L}$ polyphenols expressed in gallic acid.

The minimum values of polyphenols had oregano (Origanum vulgare) with $582.000 \mathrm{mg} / \mathrm{L}, \mathrm{St}$ John's wort (Hypericum perforatum) with $434.634 \mathrm{mg} / \mathrm{L}$, lemon balm (Melissa officinalis) with $345.540 \mathrm{mg} / \mathrm{L}$ and centaury (Centaurium erythraea) with $271.613 \mathrm{mg} / \mathrm{L}$. 


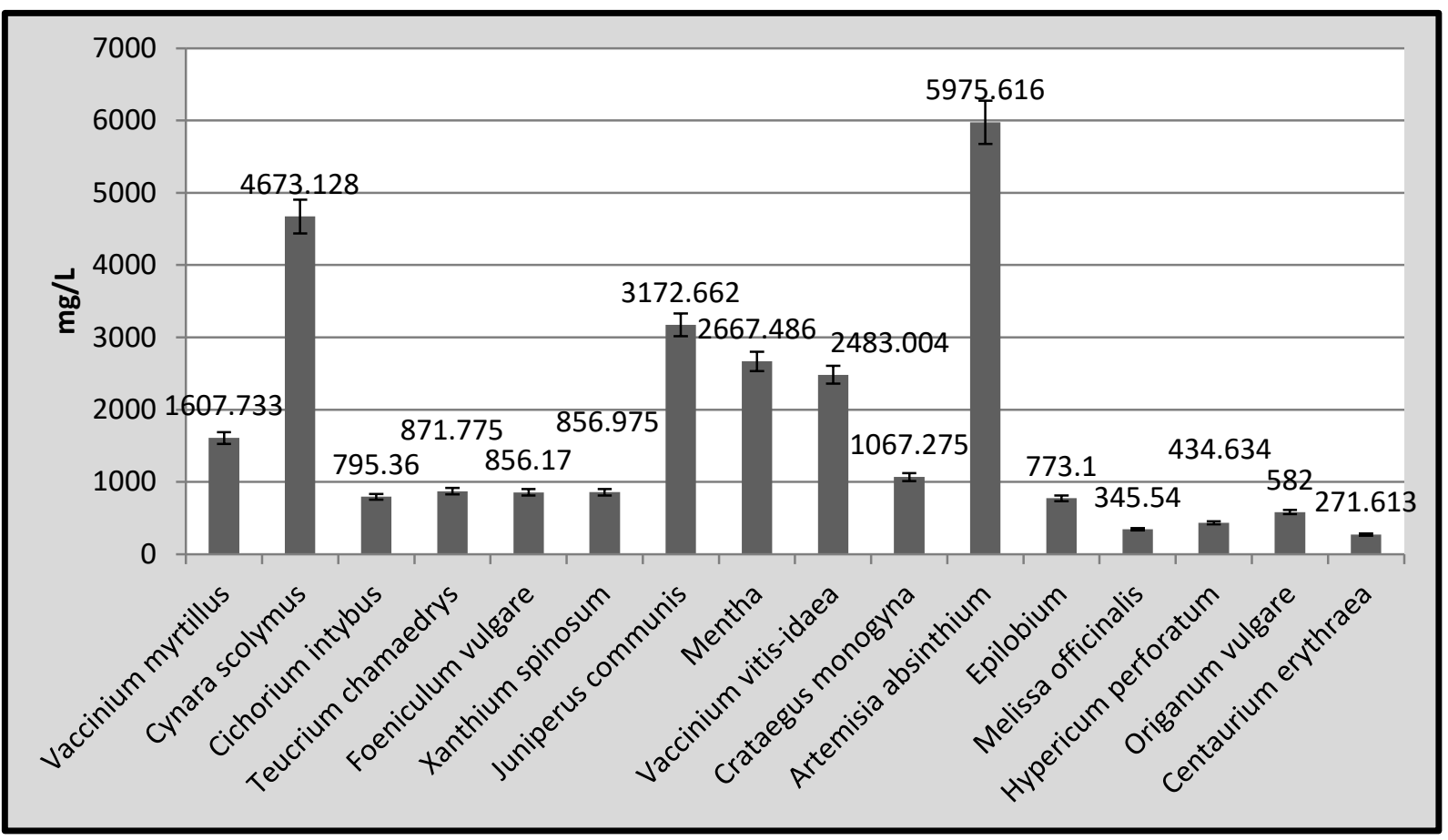

Figure 1.The identification and quantification of polyphenols from plants with bioactive potentially: bilberry (Vaccinium myrtillus), artichoke (Cynara scolymus), chicory (Cichorium intybus), dumb (Teucrium chamaedrys), fennel (Foeniculum vulgare), thorn (Xanthium spinosum), juniper (Juniperus communis), mint (Mentha), cranberry (Vaccinium vitis-idaea), hawthorn (Crataegus monogyna), wormwood (Artemisia absinthium), willow herb (Epilobium), lemon balm (Melissa officinalis), St. John's wort (Hypericum perforatum), oregano (Origanum vulgare), centaury (Centaurium erythraea)

\section{CONCLUSIONS}

Polyphenols occupies a very wide range of values based on low amounts for centaury (Centaurium erythraea) several hundred $\mathrm{mg} / \mathrm{L}$ and reaching values of several thousand $\mathrm{mg} / \mathrm{L}$ for wormwood (Artemisia absinthium).

The studied plants contain significant amounts of polyphenols. The studied plants can enter into different drink recipes with antioxidant properties, drinks especially recommended for digestive disorders.

\section{REFERENCES}

[1] S. Oancea, C. Grosu, Effect of Vaccinium myrtillus anthocyanin extract on lipid oxidation in cod liver oil, Rom. Biotech. Lett. 18(1) (2013) 7897-7903.

[2] V.T. Saponjac, J. Canadanovic-Brunet, G. Cetkovic, Dried bilberry (Vaccinium myrtillus L.) extract fractions as antioxidants and cancer cell growth inhibitors, LWT- Food Science and Technology. 61 (2: (2014) 615-621.

[3] R. Bundy et al., Artichoke leaf extract (Cynara scolymus) reduces plasma cholesterol in otherwise healthy hypercholesterolemic adults: a randomized, double blind placebo controlled trial, Phytomedicine. 15(9) (2008) 668-75.

[4] B. Wider et al., Artichoke leaf extract for treating hypercholesterolaemia, Cochrane Database Syst Rev. 2013.

[5] R.A. Street, J. Sidana, G. Prinsloo, Cichorium intybus: traditional uses, phytochemistry, pharmacology, and toxicology, Evidence-Based Complementary and Alternative Medicine, Volume 2013 (2013) Article ID 579319. 
[6] Q. Wang, J. Cui, Perspectives and utilization technologies of chicory (Cichorium intybus L.): a review, African Journal of Biotechnology. 10(11) (2011) 1966-1977.

[7] E. Bedir, R. Manyam, I.A. Khan, Neo-clerodane diterpenoids and phenylethanoid glycosides from Teucrium chamaedrys L., Phytochemistry. 63 (2003) 977-83.

[8] C. Nencini et al., Hepatotoxicity of Teucrium chamaedrys L. decoction: role of difference in the harvesting area and preparation method, Indian J Pharmacol. 46(2) (2014) 181-184.

[9] R.A. Manzoor et al., Foeniculum vulgare: A comprehensive review of its traditional use, phytochemistry, pharmacology, and safety, Arabian Journal of Chemistry. (2012).

[10] R.L. Quiroga, Meneses, R.W. Bussmann, Medicinal ethnobotany in Huacareta (Chuquisaca, Bolivia), Journal of Ethnobiology and Ethnomedicine. 8(1) (2012) 1.

[11] B.S. Gergely et al., Ethnoveterinary practices of Covasna County, Transylvania, Romania, Journal of Ethnobiology and Ethnomedicine. 11(1) (2015).

[12] S. Grasser, C. Schunko, C. R. Vogl, Gathering "tea" - from necessity to connectedness with nature. Local knowledge about wild plant gathering in the Biosphere Reserve Grosses Walsertal (Austria), Journal of Ethnobiology and Ethnomedicine. 8(1) (2012) 1.

[13] A.N. Adham, Comparative extraction methods, phytochemical constituents, fluorescence analysis and HPLC validation of rosmarinic acid content in Mentha piperita, Mentha longifolia and Osimum basilicum, Journal of Pharmacognosy and Phytochemistry. 3(6) (2015) 130-139.

[14] A. Calderone, L. Castagnoli \& G. Cesareni, Mentha: a resource for browsing integrated protein-interaction networks, Nature Methods. 10 (2013) 690-691.

[15] K.Y. Ho et al., Antioxidant Activity of Tannin Components from Vaccinium vitis-idaea L. Journal of Pharmacy and Pharmacology. 51(9) (1999) 1075-1078.

[16] M.E. Hoda et al., Stimulation of AMP-activated protein kinase and enhancement of basal glucose uptake in muscle cells by quercetin and quercetin glycosides, active principles of the antidiabetic medicinal plant Vaccinium vitis-idaea, Molecular Nutrition and Food Research. 54(7) (2010) 991-1003.

[17] O. Raspé, J.R. Kohn, S-allele diversity in Sorbus aucuparia and Crataegus monogyna (Rosaceae: Maloideae), Heredity. 88(6) (2002) 458-465.

[18] A. Castaneda-Ovando et al., Chemical studies of anthocyanins: A review, Food Chem. 113(4) (2009) 859-871.

[19] V.A. Luyckx, S. Naicker, Acute kidney injury associated with the use of traditional medicines, Nature Clinical Practice Nephrology. 4(12) (2008) 664-671.

[20] W. N. Arnold, Absinthe, Scientific American. 260 (1989) 112-117.

[21] S. Knapp, Botany: Hitchers, outcasts and wasteland beauties, Epilobium angustifolium, Nature. 467 (2010) 1037.

[22] D.O. Kennedy, G. Wake, A.B. Scholey, Modulation of Mood and Cognitive Performance Following Acute Administration of Single Doses of Melissa Officinalis (Lemon Balm) with Human CNS Nicotinic and Muscarinic Receptor-Binding Properties, Neuropsychopharmacology. 28 (2003) 1871-1881.

[23] M.Y. Kim, B Y Park, M Yoon, The anti-angiogenic herbal composition Ob-X inhibits adipose tissue growth in obese mice, International Journal of Obesity. 34 (2010) 820-830.

[24] J. Tian, F. Zhang, H. Wang, Antidepressant-like activity of adhyperforin, a novel constituent of Hypericum perforatum L., Scientific Reports. 4 (2014) 5632.

[25] P.J. Nathan, The experimental and clinical pharmacology of St John's Wort (Hypericum perforatum L.) Molecular Psychiatry. 4 (1999) 333-338.

[26] Jain S. K., Gynodioecy in Origanum vulgare: Computer Simulation of a Model, Nature. 217 (1968) 764-765.

[27] C.L. Quave, A. Pieroni, A reservoir of ethnobotanical knowledge informs resilient food security and health strategies in the Balkans, Nature Plants. 1(2) (2015) 14021.

[28] J.P. Grime, J. M. L. Mackey, D. J. Read, Floristic diversity in a model system using experimental microcosms, Nature. 328 (1987) 420-422. 